Journal of Applied Philosophy, date of acceptance: 12 August 2018

\title{
Intelligibility, Moral Loss and Injustice
}

\author{
Cécile Laborde \\ University of Oxford ${ }^{1}$
}

In Liberalism's Religion, I analyse the conception of religion that liberalism relies upon. I argue that the concept of religion should be disaggregated into its normatively salient features. When deciding whether to avert undue impingements on religious observances, or to avoid any untoward support of such observances, liberal states should not deal with 'religion' as such but, rather, with relevant dimensions of religious phenomena. States should avoid religious entanglement when 'religion' is epistemically inaccessible, socially divisive, and/or comprehensive in scope. In turn, states should show special deference to religious observances insofar as they exhibit what I call integrity - whether personal or collective. The upshot of this interpretive strategy is that liberal law need not recognise religion as such. As a result, there are gaps between the liberal construal of disaggregated religion and the lived experience of religion as a uniquely integrated experience. Are these gaps morally regrettable? Are they unjust?

My critics in this Special Issue focus on different dimensions of this general issue. Kevin Vallier urges me to give more place to intelligible, rather than accessible, reasons in my theory of public reason. Jonathan Seglow raises questions about the relationship between religious integrity and legal equality. Andrew Shorten explores the gap between collective religious interests and the interests that, I argue, should be protected by law. Matteo Bonotti raises methodological and substantive questions about whether the construal of religion by analytical philosophy and liberal law is a form of epistemic injustice. In this Article, I discuss them in turn.

\section{Response to Kevin Vallier}

Kevin Vallier clarifies and enriches my approach to public reason but also raises probing challenges to it. Here I shall focus on what he says about the relationship between the accessibility and the intelligibility of reasons in the justification of exemptions. Intelligible reasons, of which religious reasons are paradigmatic,

\footnotetext{
${ }^{1}$ Many thanks to Matteo Bonotti for organising the symposium at which most of these papers were presented (at the University of Cardiff on 9 November 2017) and for his careful work in editing this special issue.
} 
are reasons that make sense by reference to the standards of the speaker. Accessible reasons, by contrast, can be understood and assessed by the relevant public. My theory of public reason is based on the ideal of accessibility, and expressly denies the justificatory force of merely intelligible reasons. In turn, my theory of exemptions acknowledges the normative force of what I call integrity-protecting commitments, which are grounded in private, comprehensive, religious, in brief, intelligible reasons. Vallier welcomes this admission. But he objects that it is then 'not clear ... why Laborde objects to an intelligible reason requirement'. Once we seriously reflect on the moral basis of exemptions, he implies, we should accept that intelligible religious reasons have more justificatory force than most liberals have acknowledged. Vallier is correct that any theory of exemptions must have an account of the normative force of merely intelligible reasons. Yet there remain substantial differences between an accessibility- and an intelligibility-based political theory. Let me draw on them to highlight the broader differences between my theory of minimal secularism and Vallier's convergence liberalism.

Minimal secularism makes limited demands on citizens but requires that state officials appeal to accessible reasons to justify laws and policies. In addition, minimal secularism sets out independent standards of normative justification of such laws and policies, grounded in ideals of liberty and equality. The upshot is that citizens can claim exemptions by appeal to their religious views; but exemptions will be justified only if they are grounded in a public, accessible reason (such as freedom of conscience or the value of integrity) and if granting them is compatible with broader standards of liberty and equality. Convergence liberalism allows both citizens and officials to draw on any reason they find intelligible, but only laws that are justified from the perspective of all citizens' diverse sets of reasons are legitimate. It is incumbent on officials and institutions to support laws that are adequately supported by a convergence of diverse intelligible reasons. The upshot is that laws that some persons have sufficient intelligible reason to reject should not be imposed upon them: intelligible reasons can act as defeaters for laws, and ground exemptions.

Minimal secularism and convergence liberalism hold incompatible accounts of the justificatory role of accessible and intelligible reasons and, connectedly, incompatible accounts of the justification and limits of religious exemptions. Vallier's convergence liberalism allows that intelligible reasons can defeat laws. Lawmakers should not impose laws that cannot be publicly justified in terms of intelligible reasons. Paradigmatically, when a law places a substantial burden on the integrity of a religious believer, then she has sufficient intelligible reason to object to the law. Imposing a law on someone with intelligible objections to it would amount to illiberal, unjustified coercion. In those cases, Vallier argues, the law 
should be either repealed or reformed - including by granting exemptions from the law to religious

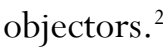

The justification of exemptions under my preferred theory of minimal secularism is different. Exemptions are not justified directly by appeal to whatever private, religious, intelligible objections some citizens have to the law. Rather, they are justified by reference to the relevant publicly accessible reason - religious freedom, freedom of conscience, or (in my preferred formulation) the value of integrity. Religious believers provide intelligible reasons in order to flesh out the relevant public reason - to show that whatever value the public reason protects is present in their own commitments and practices. Intelligible reasons have a crucial role to play, but it is an informational, heuristic rather than a directly justificatory role. This is because it is not the content of the reason that defeats the law but, rather, the role the reason plays in the exercise of a basic moral power.

Nor is this all. Under minimal secularism, it is not sufficient that the normative force of some beliefs or commitments be conveyed via appeal to an accessible reason. What I call integrity-protecting commitments (IPC) have pro tanto force, but they can be outweighed by other considerations, such as the importance of the law to the pursuit of justice. Intelligible objection to a law, therefore, is only indirectly necessary and never sufficient to ground exemptions. Exemptions are justified only if they are grounded in a reason that is publicly accessible, and if they meet independent standards of justice. The upshot is that imposing a law on someone with intelligible objections to it is often the right thing to do, all things considered. To give an example I draw on in Liberalism's Religion, it would be unjust to allow Jehovah's Witnesses to deny blood transfusions to their children, as a minimally secular state has a crucial responsibility to protect the life and basic health of children. The parents' objection has some normative force - it is an IPC, not an instance of sadistic abuse - but is not sufficient to outweigh the just interests of children.

Evidently, Vallier's convergence liberalism is much more accommodating of religious exemptions than minimal secularism. Under minimal secularism, there is no presumption that IPC should be accommodated qua IPC. Convergence liberalism, by contrast, starts from the principle that laws which some persons have sufficient intelligible reason to reject should not be imposed upon them. However, we should note that the implications of this radical-sounding principle are not entirely straightforward on Vallier's own account. He concedes that some laws can be imposed on objectors, when exemptions would generates unfair costs for majorities - his two main examples are vaccine exemptions, and draft exemptions for Ultra-Orthodox Haredim in Israel. But this move by Vallier raises two concerns. First, he needs to provide a more detailed account of why the majority's view of what costs are reasonable for

\footnotetext{
${ }^{2}$ See also Kevin Vallier, 'The Moral Basis of Exemptions', Law and Philosophy (2016) 35:1-28
} 
them to bear should be the chief determinant of the legitimacy of exemptions. One worry is that this does not speak to the hardest cases of exemptions: those affecting, not majorities, but minorities within minorities; or those generating, not material costs, but rights violations. I wonder, therefore, how Vallier's reasoning would apply to the Jehovah's Witness example I presented above.

More importantly, it is unclear how, under convergence liberalism, denying exemptions can be justified to objectors at all. In Vallier's view, a law is justified to citizens if citizens have their own intelligible reasons to accept it. But it is difficult to see how the no-exemption stance could then be justified to the Haredim, for example. Appeal to cost fairness has little weight in the face of strict religious prohibitions (particularly if the Haredim sincerely believe that they are doing their fair share for the community through their good religious works). Under convergence liberalism, coercing the Haredim to serve in the Israeli army would seem to be the paradigm of illiberal, unjustified coercion. Crucially, no such problem arises under minimal secularism, which does not hold that the Haredim's IPC are (even prima facie) sufficient to defeat the uniform application of a law. The Haredim can justifiably be coerced if, on balance, the importance of the law and the fairness of compliance costs outweigh the severity and the directness of the burden that the law imposes on them. This does not mean that there is no moral loss - we should recognise that the Haredim commitments are serious, integrity-protecting commitments, not cowardly attempts to free-ride on others. But it is, I think, one of the feature of liberal coercion that it must sometimes be justified 'with regret'.

Given this significant difference between convergence liberalism and minimal secularism, Vallier's conciliatory claim that our views on exemptions are 'nearly extensionally equivalent' is somewhat exaggerated. He has been generous in specifying my accessibility criterion further, and in drawing attention to the necessary rapprochement between accessibility and intelligibility theorists on the topic of exemptions. But there are limits to this rapprochement. Taking intelligible religious reasons seriously - as I do - does not mechanically generate the 'remarkably expansive exemptions regime' that Vallier claims I defend. The substantive conception of justice that I outline in Liberalism's Religion is hostile to exemptions that undermine the rights of women, children and sexual minorities, and that therefore contradict liberal justice. On these matters, I am curious to see which insights convergence liberalism of which Vallier is a forceful and articulate exponent - will yield.

\section{Response to Jonathan Seglow}

In his thoughtful essay, Jonathan Seglow raises a number of important further questions about integrity and exemptions. I shall consider just a few of them. The first is whether it makes sense, following Bernard Williams, to say that people can perform morally abhorrent actions with integrity. I think it does. 
Consider actions performed in tragic situations, where agents must sacrifice something of value in order to pursue something else of value - classical examples may be the ethical dilemmas in which Abraham or Antigone found themselves. There is a crucial difference between doing something morally abhorrent out of brutality, sadism, or wickedness, and doing something abhorrent 'with regret' - in full awareness of one's morally compromised position. As I illustrated above with the Jehovah's Witness example, some acts are morally abhorrent (and therefore do not even prima facie qualify for exemptions) but they may still be compatible with integrity. This is one way in which we can recognise the moral losses that the pursuit of liberal justice entails.

In Liberalism's Religion, I further distinguish between the metric of justice (IPCs that are not morally abhorrent) and principles of justice (which I call 'disproportionate burden' and 'majority bias'). A mere legal burden on an IPC is not in itself unjust. Injustice arises when the burden is disproportionate (a ratio between its severity and directness, the importance of the law to the pursuit of justice, and third-party costs) or when it operates against a background of structural majority bias (where the majority is already structurally accommodated through the formatting of institutions and laws). Seglow raises two important questions about this framework.

First, can it be reasonable to deny that exemptions are ever justified? A number of philosophers, such as Richard Arneson and Brian Leiter, are sceptical about exemptions altogether. I think they are mistaken but, arguably, their view is at least reasonable, in the sense that it could be fitted into the broad family of liberal conceptions of justice. As Seglow says, they offer a plausible interpretation of the 'quintessentially liberal egalitarian view that no group of people should enjoy greater liberty than others'. The view must be clarified further, however. Seglow parses Arneson's view as follows: 'there's no reason to defer to the dictates of a person's conscience if she is mistaken about the good, especially when, as is the case with many exemptions, they shift costs on to third parties'. I agree that exemptions must be denied when they imply unfair cost shifting (as in the Haredim case discussed above). But I am less sure that the first part of the sentence is correct. A liberal state protects conscience even if it is mistaken: the whole point of liberty of conscience is to protect diverse, possibly profoundly mistaken, beliefs and convictions. If an exemption is rejected, it is because it is not compatible with the rightful claims of others, not because it is mistaken about the good. Insofar as Arneson and Leiter deny what Rawls calls reasonable pluralism (the fact that people reasonably disagree about the good life, and some of them will naturally come to endorse valueless or mistaken ways of life), then their view is not reasonable.

Second, Seglow raises tricky questions about the majority bias principle. Majority bias is an egalitarian principle that grants minorities opportunities that are equivalent to those enjoyed by majorities, by virtue of the historical formatting of institutions. For example, in countries where the day of rest of religious majorities is also the officially recognised day of rest, members of minorities should be 
granted accommodations for religious practice on their preferred day of rest. As Seglow notes, the logic of majority bias is one of rectification of discrimination. Identifying a case of discrimination or majority bias requires that a relatively advantaged comparator group be identified (this is one difference with disproportionate burden, which is not a comparative principle in the same sense). A difficult question follows: can members of majority religions, such as Christians in many western societies, appeal to majority bias? Have historical religious majorities in effect become minorities, liable to be indirectly discriminated against by secular legislation?

One has to proceed with caution here, as one implication of the indirect discrimination paradigm would seem to be that non-religious citizens are unfairly advantaged merely because laws are secular. But this is too hasty. Consider the case made on behalf of Lilian Ladele, a registrar in the local council of Islington, who objected to performing same-sex civil partnerships on grounds of her religious beliefs. Her claim to the ECtHR was framed, not as a claim of freedom of religion but as a claim of indirect discrimination (I simplify some legal complexities). Ladele's legal counsel argued that the wrong done to her was the fact that she was treated similarly to other persons in relevantly different situations. The relevant comparator group, he suggested, is made up of 'staff members who do not have a conscientious objection to registering civil partnerships' ${ }^{3}$ But this cannot be a relevant case of majority bias: people who have no objection to the law cannot, for anti-discrimination purposes, count as a group that is unfairly advantaged. Laws by definition have a disparate impact on those who do not wish to engage in the activities that they require. The mere fact that some laws indirectly burden religious citizens cannot in and by itself raise an indirect discrimination concern. This is not to say that Ladele - and other Christian claimants cannot make a prima facie exemption claim. I think they can; but it should be under disproportionate burden, rather than majority bias. (Whether the claim should be granted is a separate question that I do not address here).

Which group counts as a 'majority' and a 'minority' in pluralistic societies, for anti-discrimination purposes, is not merely a function of its position vis-à-vis one or another piece of legislation. One needs a supplementary account of the particular patterns of structural oppression and subordination that characterise majority-minority relations (understood not as numerically unequal groups, but as unequally powerful groups). While Seglow is right to point out that Christian claimants are 'free to choose a

\footnotetext{
${ }^{3}$ Christopher McCrudden, 'Marriage Registrars, Same-Sex Relationships, and Religious Discrimination in the European Court of Human Rights', in Michel Rosenfeld \& Susanna Mancini (eds.) The Conscience Wars. Rethinking the Balance between Religion, Identity and Equality. Cambridge: Cambridge University Press, 2018.
} 
different comparator', it is incumbent upon them to prove that the advantage that comparator group enjoys is an unfair one.

\section{Response to Andrew Shorten}

In his clarifying and penetrating essay, Andrew Shorten presses me on my theory of collective exemptions and raises another set of concerns about the gap between liberal law and the lived experience of religion. In Liberalism's Religion, I argue that only those groups that exhibit a specific mode of association are eligible for exemptions from general laws, particularly laws against discrimination on suspect grounds such as gender or sexuality. Groups must (i) have a formal structure and a public doctrine, (ii) be voluntary and identificatory and (iii) exhibit a 'fit' between their structure, their purpose and their membership. Only then do they have what I call relevant coherence interests. One advantage of this framework, I think, is that it generates intuitively plausible results about the kind of associations that are cohesive and coherent enough to be granted special rights. A church with an official doctrine of male-only clergy, for example, can be exempted from laws forbidding gender discrimination. By contrast, a closely-held, for-profit corporation whose family shareholders have sincere religious beliefs cannot be exempted from general laws (such as the US contraception mandate in the Hobby Lobby 2014 Supreme Court decision) if its employees are not in the right - identificatory - relationship with the company. Likewise, a loose, diffuse community, such as the Hindu or the Muslim community, cannot enjoy formal exemptions as it lacks a formal structure as well as a relevant 'fit' between its purpose and its membership.

In response, Shorten points to several instances where associations do seem to have important coherence interests. Surely, many religious communities have an interest in their members' compliance with their norms and values - including sexual and gender norms -, and this compliance can be effected informally - through education and sanctions. Surely, too, some religious associations have an interest in providing services to the public as a whole, not merely to co-religionists, as when churches provide soup kitchens or run hospitals. Shorten is correct that these are important coherence interests. But what I argue is that they are not relevant coherence interests, where the criterion of relevance is a normative one. What I mean by relevant coherence interests are those interests that can justify collective exemptions from some laws. That religious associations might have other coherence interests is a fact about collective religion. But it is a different question whether such facts can generate legal entitlements, and it is this that I deny. I concede that I could have been clearer, however, in specifying that relevant coherence interests are through and through normative: they are an interpretive, legal, not a descriptive, sociological category. 
Associational coherence interests, as identified through specific modes of association, must reach a sufficient density, so to say, to justify special rights. Because collective exemptions entail powers of the association over the normative status of its members, personnel, or users, it is crucial that associations exhibit a tight fit between structure, ethos and membership - a fit that is missing in loose and diffuse communities, as well as in cases of provision of public services by faith groups. In both cases, a collective exemption would imply the subjection of non-members or unwilling members to arbitrary discriminatory rules. The upshot is that if a religious group seeks to discriminate on impermissible grounds, it must constitute itself as a voluntary and identificatory association, guarantee freedom of exit for its members, and have an open doctrine that justifies (to its members) the differential treatment it takes to be central to its doctrine.

Does this mean such that only religious groups that are voluntary count as properly religious? It does not. Recall that my approach is interpretive, rather than focused on the semantic or ontological question of what groups 'really' are. To say that only religious groups that are constituted as voluntary associations can claim discrimination from general laws is not to postulate that only they are properly 'religious'. Hindus, Jews, Catholics and others rightly see themselves as belonging to religious nonvoluntary communities of fate. But the question that concerns us here is a specific normative question, that of the justification of some legal privileges. The question is not: what is a religious group? It is, rather: if a group (any group) wants to discriminate on impermissible grounds, what kind of group must it be, for the purposes of the law? The normative point is that, for some groups to be granted exorbitant powers to derogate from general rules of justice, they must have relevant coherence interests.

While this account of relevant coherence interests clarifies the core cases, its implications are less clear-cut in the case of groups that exhibit a mix of purposes and interests, and that are only partly voluntary. Religious schools - on which Shorten rightly and expertly focuses - are a particularly tricky test case for the theory. It would not be wise, I think, to adopt a blanket approach to all religious schools, as this is a wide and diverse category. Generally, if schools are open to all, and not only to co-religionists, they have no relevant coherence interest and they should not be exempted from anti-discrimination laws in their staff selection. One exception might be made for teachers of religion: they can be treated differently, insofar as they also have an exemplary role - they can be expected to live the faith, not only teach it. This neat solution, however, leaves out a host of intermediary cases: for example concerning teachers of non-religious subjects in private schools with a religious ethos (on which Shorten focuses), or concerning not only religious but also gender and sexuality discrimination. My theory of coherence interests does not provide definite and conclusive guidelines about these cases, but it does offer a set of relevant criteria, notably concerning transparency and procedural fairness. 


\section{Response to Matteo Bonotti}

Matteo Bonotti, in a rich, wide-ranging piece, goes to the heart of the methodological and substantive issues that are the subject of this essay - the relationship between epistemic gaps, moral loss and injustice. How do our concepts and conceptions of religion relate to lived social and spiritual experiences? Bonotti offers a set of fascinating reflections, at the intersection of what we may call Taylorian and Frickerian insights. Charles Taylor argues that language shapes and constitutes reality, instead of merely designating it. Miranda Fricker points out that the process through which a society builds the epistemic resources necessary to understand and make sense of the experiences of certain groups can involve substantial injustice (which she calls hermeneutical epistemic injustice), and Bonotti points out that the language deployed in this process may often ill fit or distort the experience of dominated groups. Applying these insights to religion, we can ask whether the Anglophone conception of religion shapes institutions, laws and social attitudes in a way that overlooks and distorts linguistically-codified experiences and ways of relating to the world, notably by privileging belief-based, individualistic, voluntaristic, Protestant religious attitudes.

My response to this challenge in Liberalism's Religion is two-pronged. First, in the opening chapter of the book, I show that liberal egalitarian philosophers eschew the language of religion altogether to opt instead for what Rawls calls 'conceptions of the good'. As Bonotti usefully illustrates, this terminology belongs to a more natural semantic metalanguage and is therefore less parochial and more inclusive than the term religion. One example I refer to is that of the inhabitants of the Indus region, who were made into members of a (mostly western-invented) 'Hindu religion', and forced artificially to distinguish between the religious (praying, rituals) and the non-religious (food, dress) dimensions of their communal life. By contrast, if we focus on their conception of the good life, instead of construing their 'religion' on the Protestant model, we can track their lived, communal, multi-dimensional experience more reliably. Second, in the rest of Liberalism's Religion, I address what I think are the remaining problems with the Rawlsian category of conception of the good. In brief, the category is too vague and too elusive to do the distinctive interpretive and normative work that legal-political concepts should do.

Why should some 'conceptions of the good' be worthy of special respect and deference, via exemptions from general laws? Why should the state be neutral about the good? Why exactly should there be a separation between the state and 'conceptions of the good'? In answering these questions, I show that neither the term religion nor the term 'conception of the good' are fit for purpose. Separation between state and religion, and neutrality towards the good, should be replaced with a more complex account of the dimensions of the good/religion that pose problems for liberal legitimacy. Likewise, while the general value of freedom of religion can be interpreted via broad moral freedom (à la Rawls or Dworkin), the 
specific values that justify legal exemptions should be grounded in a more precise ideal, which I call integrity. This disaggregation of both religion and 'conception of the good' answers Bonotti's legitimate worries about both the intellectualist and the voluntarist bias of the Rawlsian notion of conception of the good. My disaggregated conception of religion emphasizes its social, communal, collective, cultural and political dimensions, and thereby avoids Protestantized reductions. Admittedly, there is space for the intellectualist dimension of religion (in my theory of accessible public reason) as well as for its voluntarist dimension (in my theory of collective religious exemptions from discrimination legislation) but that space is both clearly delimited and justified philosophically - not postulated by reference to a descriptive account of what religion really 'is'.

This interpretive process, then, is neither Taylorian nor Frickerian. Contra Taylor, legal language does not fully constitute social reality but, rather, selectively interprets its normatively salient dimensions. This might involve some moral loss but, contra Fricker, it need not result in hermeneutical injustice. To illustrate: when religious communities complain that the liberal law of freedom of speech dissolves and secularises the sin of blasphemy or apostasy, they are right that something is lost in legal translation (sinful actions against God cannot be reduced to secular harms or offences). But this epistemic or hermeneutical misfit does not constitute an injustice, by liberal lights. This is because liberal justice primarily protects the moral capacities and rights of individuals, not those of transpersonal or impersonal collectives such as deities or communities. In a liberal state, individuals should be free to develop, pursue and alter their way of experiencing the good (here I borrow Bonotti's felicitous phrase). It follows that they can criticise, repudiate and leave their religious communities: hence the importance of freedom of religion. Does this clash with the experience of integrated communal religious lives? It does. But this is not unjust. Liberal law of freedom of religion does not claim to describe how individuals in fact experience having a religion, nor to prescribe how individuals should relate to their religion. Just as the law of divorce emphasises the contractual, voluntary nature of marriage without describing how marriage is experienced, and without prescribing the value of divorce, likewise, the law of freedom of religion protects a moral capability - a protection against certain types of coercion and persecution- without postulating that religion should be experienced as a voluntary choice.

Bonotti further asks about how my liberal construal of freedom of religion relates to the 'thicker and more controversial' conception he detects in my earlier work on critical republicanism. In my 2008 book Critical Republicanism, I defended an ideal of non-domination in relation to religion. Non-domination is not, in my view, a thick ideal, because it is not rooted in a comprehensive ideal of secular autonomy from religion, and it can be endorsed from the perspective of a range of reasonable worldviews. As I wrote, 'nothing about non-domination requires that individuals break free from their religious or 
communal attachments; nor does the ideal imply that the good life is a life of autonomy' ${ }^{4}$ Nondomination is a more modest ideal of discursive control, which demands what I call minimal autonomy where people must have autonomy-related capabilities, but they do not have to exercise them. In its focus on the procedural, rather than substantive dimensions of freedom of (and from) religion, the republicanism of non-domination is aligned with liberalism. As I argue in Liberalism's Religion, liberalism is a broad church, a family of reasonable conceptions of liberal justice. Critical republicanism is one such conception.

A final word on liberal conceptions of religion. It is correct, as many critics have pointed out, that liberal law indirectly shapes and transforms religious dispositions and sensibilities. Just as Rawls conceded 'with regret' that liberal education, in the process of inculcating the political virtues of mutual respect and tolerance, has a profound impact on religious lives, we must accept that, even though the point and purpose of liberal law is partial and limited, it does shape social experience in ways that incidentally, yet predictably, corrode communal, communitarian practices. Is this a symptom of an unjustly sectarian, Protestantized bias, or is it a natural side-effect of the moral individualism central to liberalism (which may or may not be connected to Protestant religion)? This, I think, is the key question. If liberalism is ill-suited to communal ways of life, it is because it is committed to its own moral ideals notably the idea that the individual is the basic unit of moral respect - not because it operates with a distorted concept of religion. To that extent, the conceptual and genealogical questions I introduce in Chapter 1 - and upon which Bonotti focuses - are overshadowed by the substantive, normative questions I pursue in the rest of the book. Bonotti's piece - as well as those of the other contributors - has forced me to think harder about the overall coherence and integrity of Liberalism's Religion, and I am deeply grateful to them all.

\footnotetext{
${ }^{4}$ Cécile Laborde, Critical Republicanism. The Hijab Controversy and Political Philosophy. Oxford: Oxford University Press, 2018.
} 